\title{
COMMUNICATIONS
}

\section{EXPERIMENTAL TRACHOMA PRODUCED BY CULTURED VIRUS. Part II}

\author{
BY \\ L. H. COLLIER*, STEWART DUKE-ELDER $\dagger$, AND BARRIE \\ R. JONES †
}

\section{INTRODUCTION}

IN a previous paper (Collier, Duke-Elder, and Jones, 1958) we described the results of inoculating human volunteers with virus isolated by Collier and Sowa (1958) from a patient in the Gambia with trachoma. Three volunteers were inoculated by the conjunctival route, and in one, an anophthalmic man, an unequivocal infection was induced with all the conjunctival and laboratory signs of trachoma. The paramount importance of establishing the aetiology of this disease beyond all doubt required the inoculation of further human volunteers so that the course of the experimental infection in the cornea could be observed. At the same time, the opportunity was taken to test a strain of virus differing somewhat in morphology from that used for the first experiments.

\section{Material AND Methods}

Virus.-The G17 strain of trachoma virus used for inoculation has been more fully described elsewhere (Collier, 1959; Sowa and Collier, 1960). It was isolated from a trachomatous patient in the Gambia, and differs from most strains in its morphology as seen in chick embryo yolk-sac smears. Like all the other strains so far isolated, it induces the formation of numerous free elementary bodies (Collier and Sowa, 1958); in addition to these, however, it forms numerous compact aggregates of virus particles surrounding a vacuole or vacuoles. These aggregates appear in every chick embryo passage; they stain intensely with iodine, and appear to contain a carbohydrate, probably glycogen. This is interesting in view of the presence of this substance in conjunctival inclusion bodies.

Inoculum.-Virus of the eighteenth egg passage was used. The yolk sac was removed from an embryo which was dying on the morning of the experiment. A Giemsa-stained smear showed numerous elementary bodies and aggregates of virus. The yolk sac was blended for $1 \mathrm{~min}$. in an M.S.E. homogenizer with twice its weight of phosphate-buffered

* Medical Research Council, Trachoma Research Group, Lister Institute of Preventive Medicine.

+ Institute of Ophthalmology, University of London.

5 
saline (PBS) (Dulbecco and Vogt, 1954). The resulting 33 per cent. suspension was kept on ice until it was used for inoculation $4 \mathrm{hrs}$ later.

Control Yolk-sac Suspension.-For inoculation of the control eye, a suspension of normal yolk sac was similarly prepared.

Titration of Inoculum.-Ten-fold serial dilutions of infected yolk-sac suspension were made in PBS; $0.3 \mathrm{ml}$. of each dilution was injected into five 6-day embryonate eggs by the yolk-sac route. Calculated by the method of Reed and Muench (1938) in terms of the dose capable of infecting 50 per cent. of the inoculated embryos $\left(\operatorname{EID}_{50}\right)$, the titre was $10^{5 \cdot 2} \mathrm{EID}_{50} / \mathrm{ml}$.

Bacteriological Sterility Tests.-Both infected and control yolk sacs were tested for bacterial contaminants as previously described (Collier and others, 1958) with negative results.

Inoculation Technique.-After the conjunctiva had been anaesthetized by the instillation of 4 per cent. cocaine, the right upper lid was everted and the tarsal conjunctiva and upper fornix were rubbed firmly with a small cotton-wool swab moistened with the infected yolk-sac suspension. The left eye was similarly treated with normal yolk-sac suspension.

Examinations for Conjunctival Inclusions, and Complement-Fixation Tests.-The methods used were those described by Collier and others (1958).

Virus Isolation.-After instillation of 4 per cent. cocaine and 1/1,000 adrenaline, conjunctival scrapings were taken with a small metal spatula, and transferred to $0.5 \mathrm{ml}$. 0.85 per cent. saline containing 10,000 $\mu \mathrm{g}$. streptomycin. On and after D 63, 1,000 $\mu \mathrm{g}$. Polymyxin B was added in addition to the streptomycin. After storage on ice for approximately $4 \mathrm{hrs}, 0.5 \mathrm{ml} .0 .85$ per cent. saline was added, and the material was repeatedly expelled from a tuberculin syringe through a No. 12 needle to break up cell clumps. Aliquots of the suspension were then inoculated into the yolk sacs of three 6- to 8-day chick embryos.

Skin Test Antigens.-Frei antigen was prepared at The London Hospital from a yolksac culture of lymphogranuloma virus, partially purified by differential centrifugation and heated at $100^{\circ} \mathrm{C}$. for 20 minutes. The control antigen was an extract of normal yolk sac similarly treated. Trachoma antigens and control material were made at the Lister Institute by a similar method. 'The viral antigens were titrated by the chessboard method against lymphogranuloma serum; a two-fold dilution of the optimal antigen concentration wa used for the skin test.

\section{RESULTS}

\section{Experiment IV}

Our fourth blind volunteer was a white man, born in 1907 with congenital dislocation of the lenses. After an operation in 1920 he had no perception of light in the right eye. In 1932 he developed a retinal detachment in the left eye, which became painful and was excised the following year. Apart from a short period of inflammation in the right eye in 1948, he had no discomfort or discharge from it. The left socket produced a moderate discharge which was kept in control by twice daily saline irrigations.

In 1949 he had an inflammation of a gland in the left groin. This did not break down and it was not associated with any genito-urinary symptoms or obvious superficial sepsis in the region. 


\section{Clinical Observations}

The lids and conjunctiva of the right eye were normal (Fig. $1 a$ and $b$ ) apart from minimal papillary hypertrophy of the lower tarsal conjunctiva, some retention cysts and a single follicle in the lower fornix.

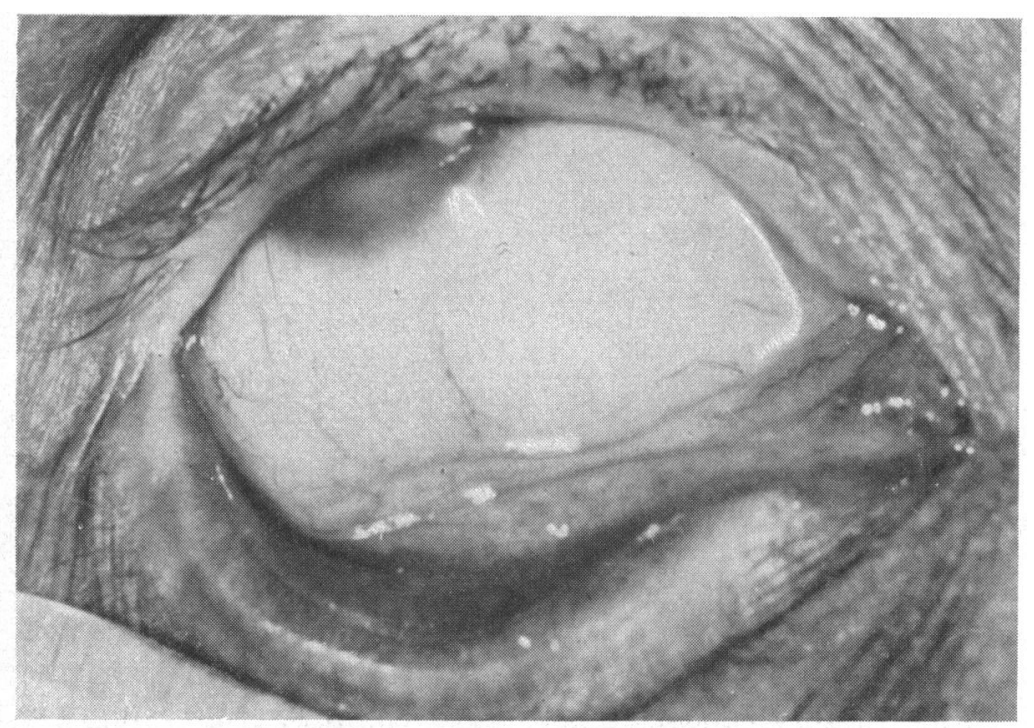

(a)

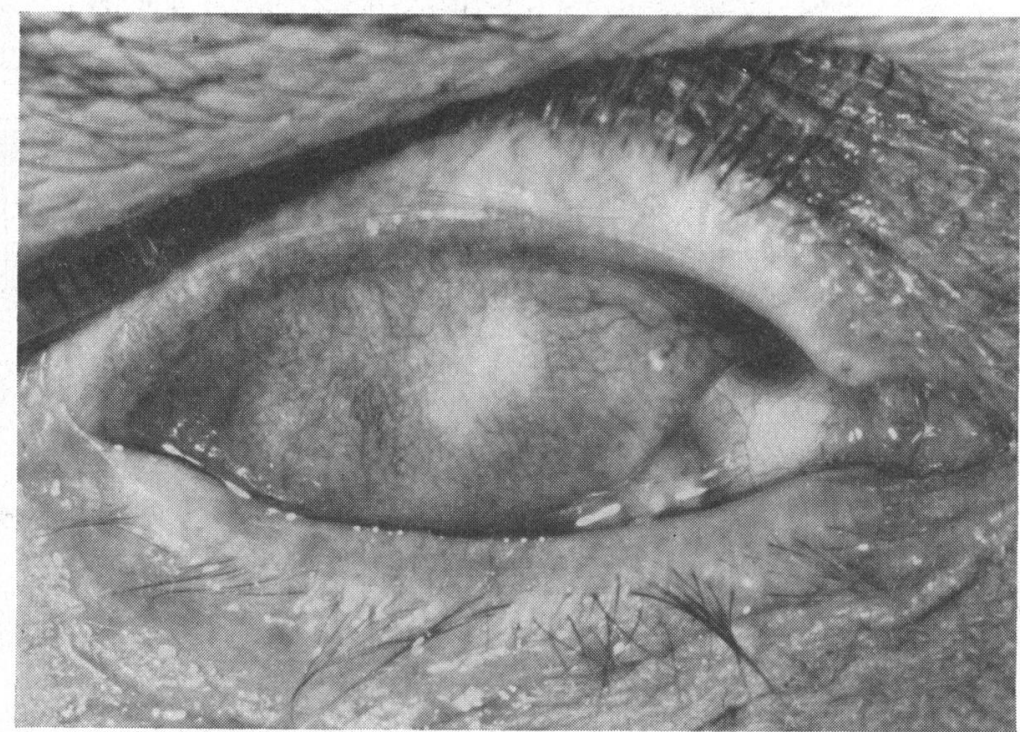

(b)

FIG. $1(a, b)$.-D 0: Right eye and left socket before inoculation. (a) right lower fornix; (b) right upper tarsus.

A central ragged band-shaped degeneration was present in the cornea (Fig. 1c, overleaf). The upper and lower borders presented the typical fenestrated opacification at the level of Bowman's membrane, whereas the 


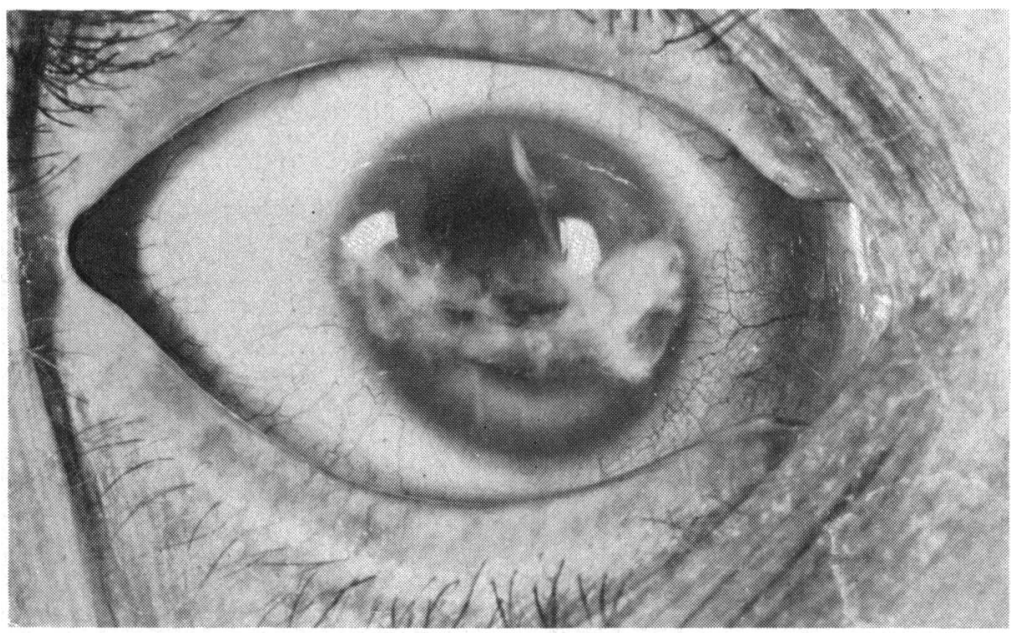

Fig. 1(c).-D 0: Right cornea before inoculation.

central area consisted of irregular opaque lamellae. A brown line was present and some very fine superficial vessels were visible near its medial and lateral extremities. The surface of the cornea was intact and did not stain with either fluorescein or Bengal rose. The upper third of the cornea was clear apart from a linear stromal opacity extending obliquely down from the limbus towards the band-shaped degeneration. An arcus senilis was present in the lower quarter. The limbus was normal above and below. The anterior chamber was moderately shallow and there was no red reflex through the small central circular aphakic pupil.

On the left side the lids were normal but a moderate quantity of mucopus was present in the socket (Fig. 1d). Marked papillary hypertrophy affected the whole conjunctiva, especially the tarsal areas. No follicles were seen.

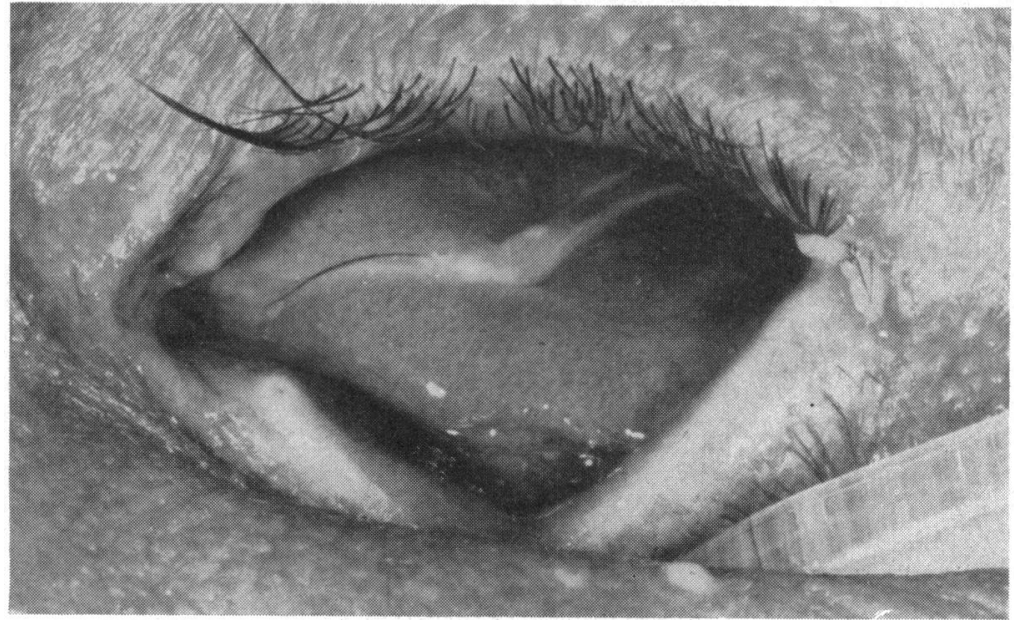

FIG. 1(d).-D 0: Left socket before inoculation. 
The configuration of the socket made slit-lamp examination of the tarsal conjunctiva extremely difficult.

Clinical Course (Table I, overleaf).- There was slight hyperaemia of the right lower tarsal conjunctiva and a slight mucoid discharge on the first day after inoculation (D 1). On D 2 the patient awoke with a discharging right eye and a running nose, and felt as though he had a "cold in his eye". There was a copious mucopurulent discharge from this eye on D 3, associated with oedema and erythema of the lids as well as gross oedema and hyperaemia of the entire conjunctiva; the associated tenderness precluded eversion of the lids. There was a diffuse roughening and opacification of the corneal epithelium, with six small whitish spots in the epithelium near the upper limbus. No stromal change had occurred and the limbus was oedematous only. There was slight discomfort and tenderness over his right preauricular node.

During D 4 and 5 (Fig. $2 a, b, c$ ) the discharge was less copious from the right eye, which became less "gritty" and "sore". On D 6 the oedema was less severe but the conjunctiva of the lids and fornices showed a diffuse infiltration which largely obscured the early papillary hypertrophy in the tarsal areas. Small avascular cellular foci of infiltration were already discernible in the tarsal areas, in the lower fornix, at the upper border of the upper tarsal plate, and especially in the triangular fields medial and lateral

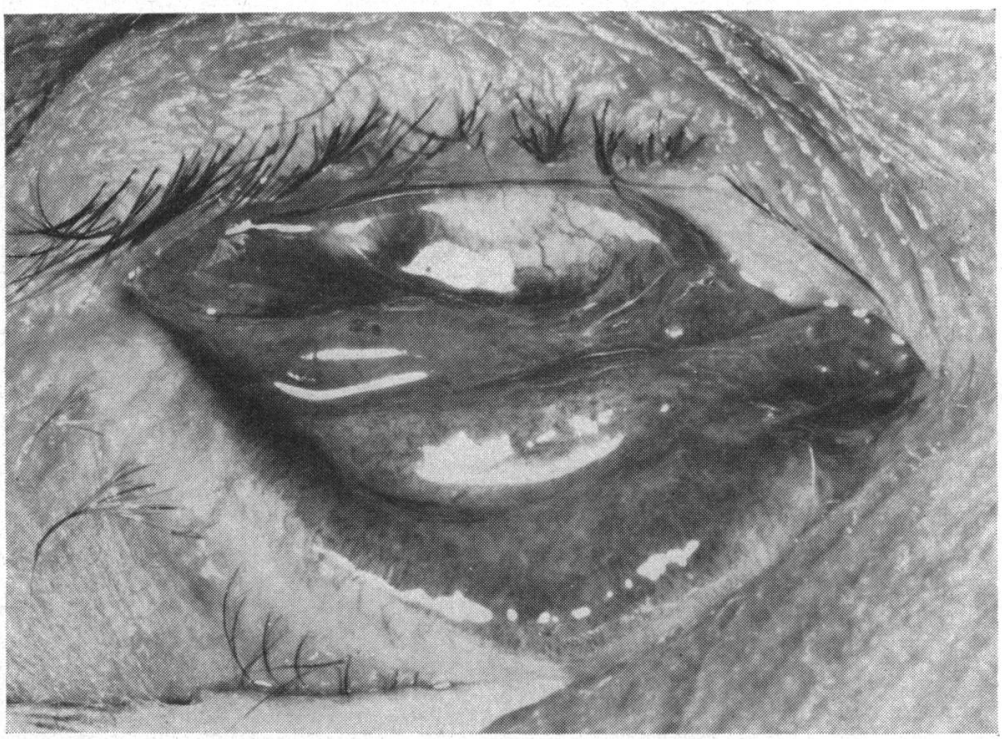

FIG. 2(a).-D 5: Right eye, showing intense oedema and injection of the conjunctiva with diffuse infiltration; lower lid and fornix. 
TABLE I

\begin{tabular}{|c|c|c|c|c|c|c|c|c|c|c|c|c|}
\hline \multirow[b]{2}{*}{$\begin{array}{l}\text { Day } \\
\text { after } \\
\text { Inocu- } \\
\text { lation }\end{array}$} & \multirow[b]{2}{*}{ Treatment } & \multicolumn{11}{|c|}{ Right Conjunctiva, etc. } \\
\hline & & 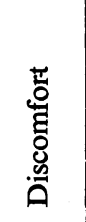 & 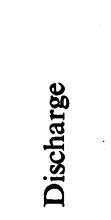 & 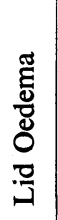 & 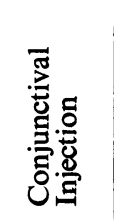 & 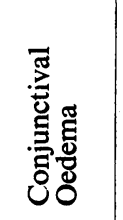 & 象兽 & 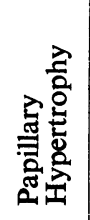 & 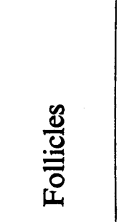 & 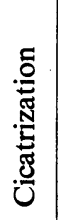 & 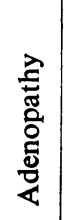 & 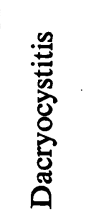 \\
\hline $\begin{array}{lr}\text { D } & 0 \\
\text { D } & 1 \\
\text { D } & 2 \\
\text { D } & 3 \\
\text { D } & 6 \\
\text { D } & 9 \\
\text { D } & 13 \\
\text { D } & 20 \\
\text { D } & 28 \\
\text { D } & 50 \\
\text { D } & 55 \\
\text { D } & 60 \\
\text { D } & 62 \\
\text { D } & 64 \\
\text { D } & 66 \\
\text { D } & 69 \\
\text { D } & 70 \\
\text { D } & 73 \\
\text { D } & 79 \\
\text { D } & 91 \\
\text { D } & 100 \\
\text { D } & 145 \\
\text { D } & 246 \\
& \end{array}$ & $\begin{array}{l}\text { Inoculation } \\
\\
\text { Intra- } \\
\text { muscular } \\
\text { Penicillin }\end{array}$ & $\begin{array}{r}+ \\
+++ \\
+++ \\
+++ \\
+++ \\
++ \\
+ \\
++ \\
+ \\
\\
+ \\
+ \\
+ \\
+\end{array}$ & $\begin{array}{r}+ \\
+++ \\
+++ \\
+++ \\
+++ \\
++ \\
+ \\
+ \\
+ \\
+ \\
+ \\
+ \\
+ \\
+ \\
+ \\
+ \\
+\end{array}$ & $\begin{array}{r}+ \\
++ \\
+\end{array}$ & $\begin{array}{r}+ \\
+++ \\
++++ \\
++++ \\
+++ \\
+++ \\
++ \\
++ \\
+++ \\
++ \\
+ \\
++ \\
++ \\
++ \\
+++ \\
+ \\
. \\
+\end{array}$ & $\begin{array}{r}+ \\
+++ \\
+++ \\
+++ \\
++ \\
+ \\
+ \\
+ \\
+ \\
+ \\
+ \\
+ \\
\cdot \\
\cdot \\
\dot{+}\end{array}$ & $\begin{array}{r}++ \\
+++ \\
+++ \\
+++ \\
+++ \\
+++ \\
+++ \\
+++ \\
++ \\
++ \\
++ \\
++ \\
++ \\
\cdot \\
\cdot \\
+\end{array}$ & $\begin{array}{r}t \\
+ \\
++ \\
++ \\
++ \\
+++ \\
+++ \\
+++ \\
+++ \\
+++ \\
+++ \\
+++ \\
++ \\
+ \\
+ \\
\dot{+} \\
+\end{array}$ & $\begin{array}{r}+ \\
++ \\
++ \\
++ \\
++t \\
+++ \\
+++t \\
++++ \\
++++ \\
+++t \\
++++ \\
++++ \\
\cdot \\
\cdot \\
\dot{+}+ \\
++ \\
+\end{array}$ & $\begin{array}{r}\dot{\bullet} \\
\dot{+} \\
+ \\
+ \\
++ \\
++\end{array}$ & $\begin{array}{r}+ \\
+ \\
+ \\
+ \\
+ \\
++ \\
++ \\
+\end{array}$ & $\begin{array}{r}+ \\
+++ \\
++ \\
++ \\
++ \\
++ \\
++ \\
++ \\
\dot{ } \\
\dot{+} \\
+\end{array}$ \\
\hline
\end{tabular}

- Not observed

+ Minimal

++ Slight

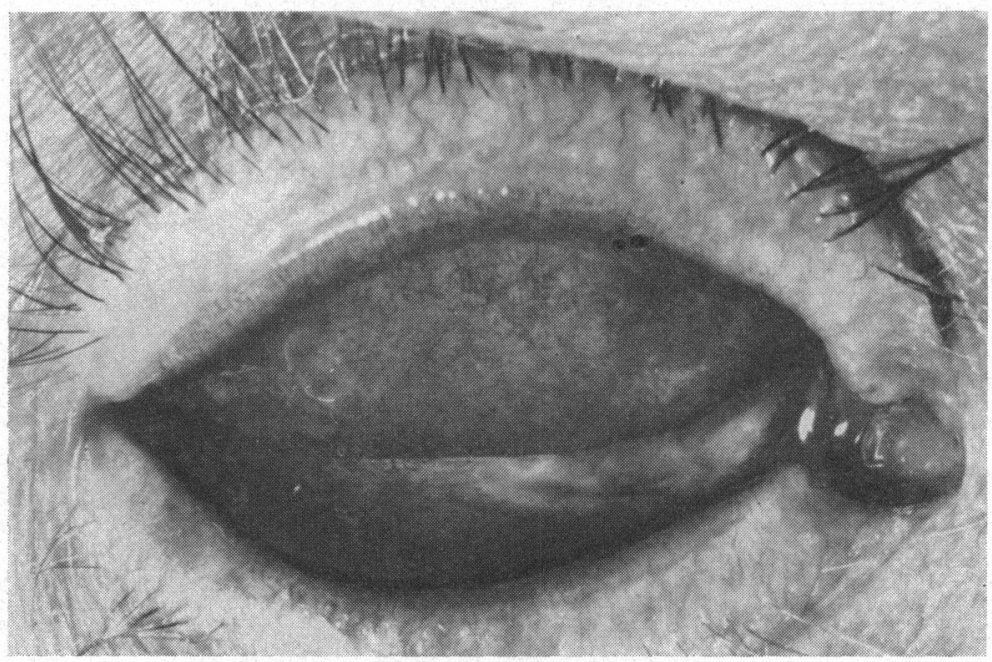

을 
SUMMARY OF CLINICAL COURSE

\begin{tabular}{|c|c|c|c|c|c|c|c|c|c|c|c|c|c|c|c|c|}
\hline \multicolumn{7}{|c|}{ Right Cornea } & \multicolumn{10}{|c|}{ Left Socket } \\
\hline 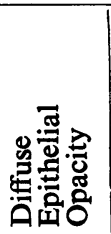 & 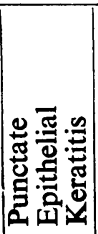 & 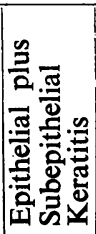 & 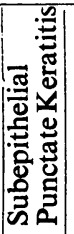 & 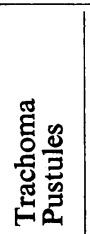 & 茎 & 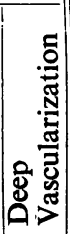 & $\begin{array}{l}\text { 녕 } \\
\text { 명 } \\
800 \\
0\end{array}$ & 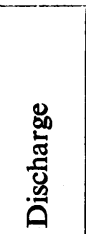 & 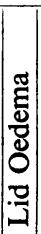 & 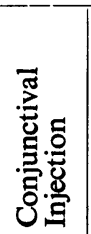 & 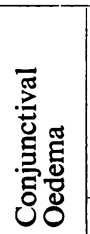 & 总兽 & 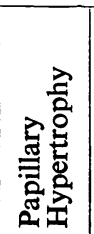 & 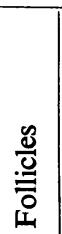 & 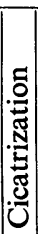 & 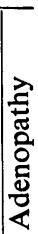 \\
\hline $\begin{array}{r}+ \\
++ \\
++t \\
++++ \\
++++ \\
++++ \\
+++ \\
++ \\
+ \\
+ \\
+ \\
++ \\
++ \\
++ \\
+ \\
+ \\
+\end{array}$ & $\begin{array}{r}+ \\
+ \\
++ \\
+++ \\
+++ \\
+++ \\
++ \\
++ \\
+ \\
+ \\
++ \\
++ \\
++ \\
\cdot \\
\cdot\end{array}$ & $\begin{array}{r}+ \\
+++ \\
+++ \\
++t \\
++ \\
++ \\
++ \\
+ \\
+ \\
+ \\
++ \\
++ \\
+ \\
\cdot \\
\cdot\end{array}$ & $\begin{array}{r} \\
+ \\
+ \\
++ \\
++ \\
+ \\
+ \\
+ \\
+ \\
+ \\
+ \\
+ \\
\cdot \\
\cdot \\
\cdot \\
+ \\
+\end{array}$ & $\begin{array}{r}+ \\
+ \\
+ \\
+ \\
+ \\
+ \\
+ \\
+ \\
+ \\
+ \\
\\
. \\
.\end{array}$ & $\begin{array}{r} \\
+ \\
++ \\
+++ \\
+++ \\
+++ \\
+++ \\
+++ \\
+++ \\
+++ \\
+++ \\
\cdot \\
\cdot \\
\cdot \\
++ \\
++ \\
+\end{array}$ & $\begin{array}{r} \\
\\
+ \\
+ \\
+ \\
+ \\
+ \\
+ \\
\cdot \\
\cdot \\
\cdot \\
+ \\
+ \\
+\end{array}$ & $\begin{array}{r}++ \\
++ \\
++ \\
+++ \\
+++ \\
\dot{.} \\
.\end{array}$ & $\begin{array}{r}+ \\
+ \\
+ \\
+ \\
+ \\
+ \\
+ \\
+ \\
++ \\
+ \\
+ \\
++ \\
++ \\
++ \\
++ \\
+ \\
+ \\
+ \\
\cdot \\
\cdot \\
+ \\
+ \\
+ \\
+\end{array}$ & \begin{tabular}{|l} 
\\
\\
\\
+ \\
+ \\
+
\end{tabular} & $\begin{array}{r}+t \\
++ \\
++ \\
++ \\
++ \\
++ \\
++ \\
+.+ \\
++ \\
++ \\
++ \\
+++ \\
+++ \\
+++ \\
+++ \\
+++ \\
\cdot \\
\cdot \\
\cdot \\
++ \\
++ \\
++ \\
++\end{array}$ & $\begin{array}{r}+ \\
++t \\
+++ \\
+++ \\
++ \\
\cdot \\
\cdot\end{array}$ & $\begin{array}{r}+ \\
+ \\
+ \\
+ \\
+ \\
+ \\
+ \\
+ \\
+ \\
+ \\
+ \\
++ \\
+++ \\
+++ \\
+++ \\
+++ \\
+ \\
\cdot \\
\dot{+} \\
+ \\
+ \\
+ \\
+ \\
+\end{array}$ & 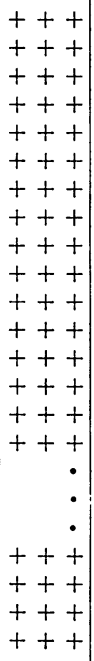 & $\begin{array}{r}+ \\
++ \\
\cdot \\
\cdot \\
\cdot \\
+\end{array}$ & $\dot{\bullet}$ & $\begin{array}{l}+ \\
+ \\
+ \\
+ \\
+ \\
\text {. } \\
\text { - }\end{array}$ \\
\hline
\end{tabular}

+++ Marked

+++ Very marked

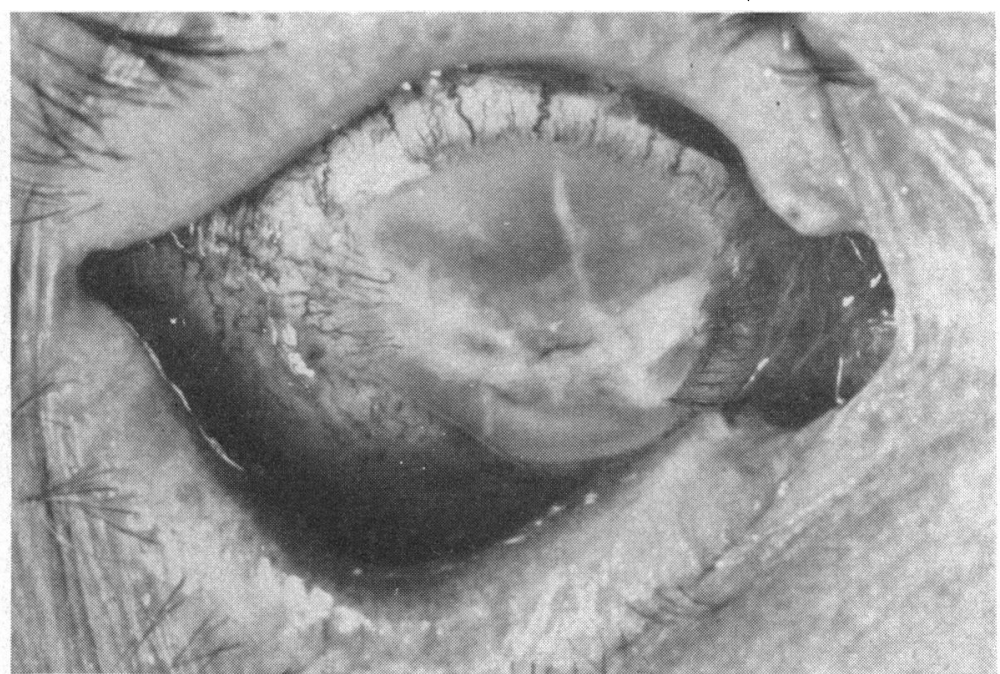

FIG. 2(c).-D 5: Right eye, showing diffuse opacification of corneal epithelium with punctate keratitis. Limbal vessels congested; hanging from lower and medial third of cornea is an elongated blob of mucus. 
to the tarsus, where the surface had become frankly granular. The bulbar conjunctiva was slightly infiltrated but was less chemotic, and a subconjunctival haemorrhage had occurred. The pre-auricular node was slightly larger. The corneal epithelium was diffusely roughened and opaque (Fig. 2c). The six marginal spots noted in the epithelium on D 3 had gone and diffuse dirty white infiltrations were present under their former sites. Two small subepithelial abscesses had developed in the upper cornea, $2 \mathrm{~mm}$. from the limbus. There was closely grouped punctate staining with Bengal rose over these two lesions; elsewhere in the upper cornea there were numerous punctate or blotchy staining areas, which stained poorly or not at all with fluorescein although the dye stained numerous other points. The subepithelial abscesses absorbed the dye slowly. The vessels at the limbus were engorged and the vessels running into the extremities of the bandshaped degeneration had enlarged.

On D 8 the right eye became very "gritty" and painful. On D 9 the subepithelial abscess in the nasal part of the cornea was smaller, but that in the temporal side was larger and a small irregular subepithelial infiltration was present over the oblique linear opacity. The patient was given 1 per cent. atropine drops three times daily. By D 13 he was having no pain although the eye continued to discharge. The lids were less swollen. Both tarsal plates were granular because of marked papillary hypertrophy and the conjunctiva of the plica and lower fornix showed the development of early follicles. The vessels at the limbus were more congested and appeared to have advanced irregularly.

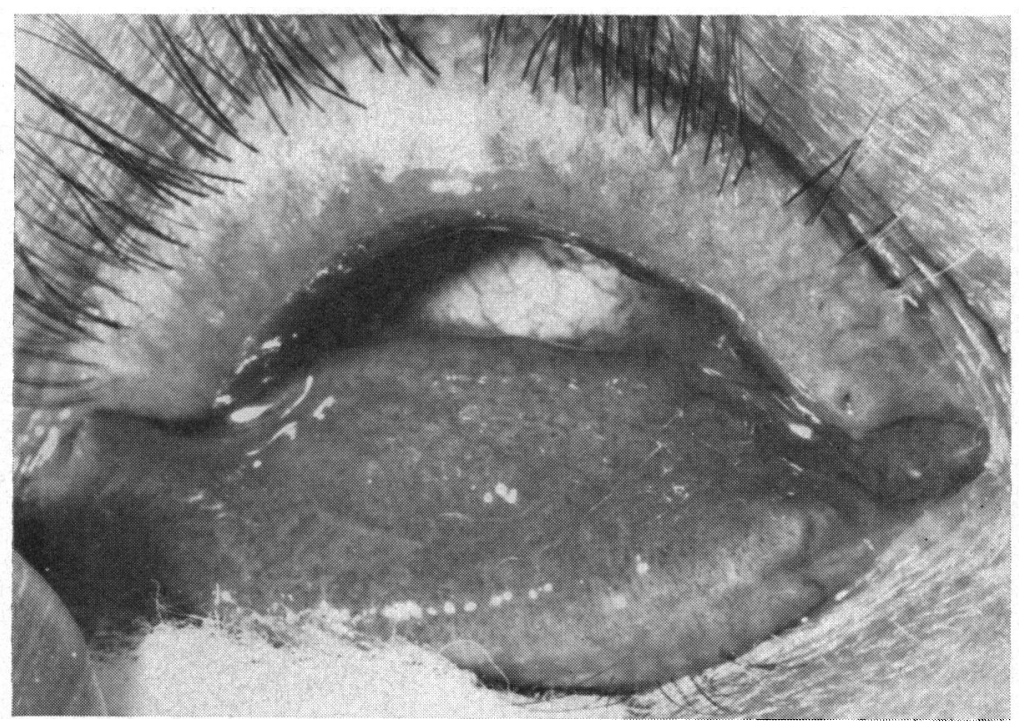

FIG. 3(a).-D 20: Right eye, showing intense papillary hypertrophy of lower tarsal conjunctiva. 


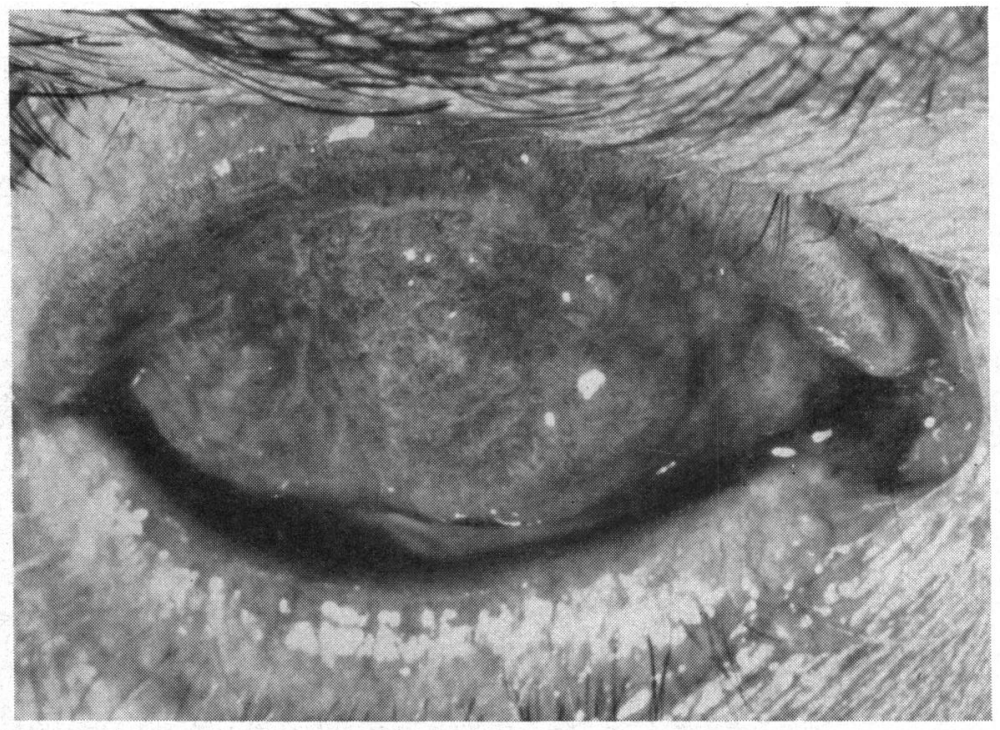

(b)

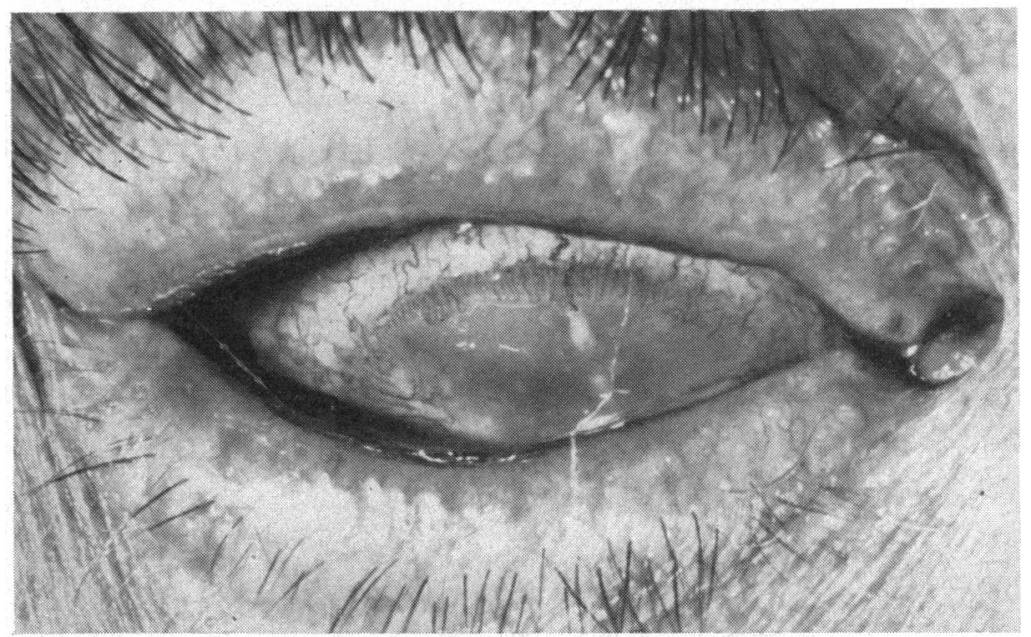

(c)

FIG. 3.-D 20: Right eye, showing intense papillary hypertrophy; (b) upper tarsal conjunctiva; $(c)$ pannus advancing into the superficial opacity in the cornea.

On D 15 and D 20 a further decrease in discomfort was reported. There was no longer any lid oedema and the discharge was watery rather than mucopurulent. The changes in the conjunctiva noted on D 13 had become more marked (Fig. $3 a$ and $b$ ) and the superficial vessels at the upper limbus had definitely advanced into the cornea (Fig. $3 c$ ). The corneal epithelium remained diffusely opaque, but the two early subepithelial abscesses had run their course and were difficult to identify amid the diffuse epithelial and subepithelial haze. The abscess on the linear opacity was still present and two additional small ones had developed on the temporal side. 
By D 28 there was less discomfort but the eye was still watery. The palpable pre-auricular, node was slightly tender. Papillary hypertrophy on both tarsal plates was more intense and the follicles in the lower fornix and upper tarsal plate had enlarged. Further micro-abscesses were still developing in the cornea although it was clearer as a whole; the reduction in general haze made it easier to discern the position of the previous abscesses and to observe the marginal subepithelial opacification into which the limbal vessels were advancing. One leash of vessels extended down over the oblique opacity to the position of a previous abscess.

When seen on D 50 (Fig. 4) the right eye had been uncomfortable for a few days. The lids were again slightly oedematous and there was a tender fullness over the lacrimal sac. The follicular and papillary conjunctivitis continued. The patient still had an active punctate keratitis in which the lesions consisted of slightly raised ragged dots made up of grouped opaque epithelial cells, an appearance which was soon associated with an underlying subepithelial and superficial stromal infiltration of a faintly yellowish colour. Each lesion ran a course of a week or two to leave an irregular subepithelial opacity often involving Bowman's membrane as well as the superficial stroma. Superficial vessels were growing further into the cornea but were less congested than on D 20 (Fig. 4c).

By D 55 the right eye was very much more comfortable and was scarcely watering. There was no oedema of the lids and the pain in the lacrimal sac region had gone although the sac was still tender and just palpable. The pre-auricular node was still palpable but no longer tender. There was a notable absence of oedema of the palpebral and bulbar conjunctiva. The

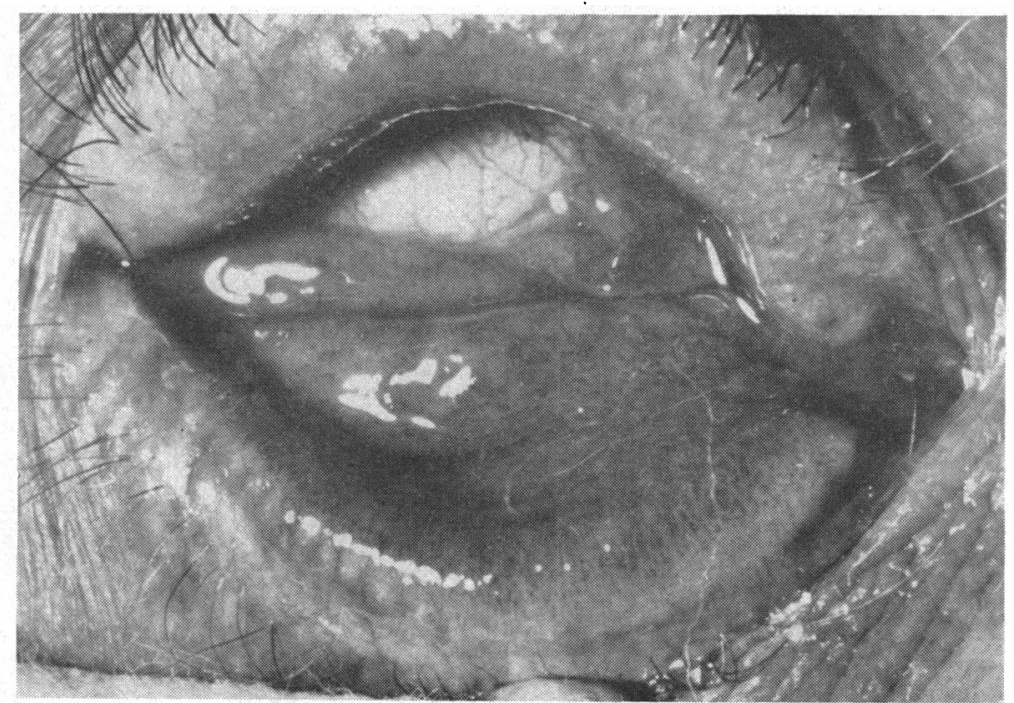

FIG. 4(a).-D 50: Right eye, showing numerous follicles amid intense papillary hypertrophy of (a) lower tarsal conjunctiva. 


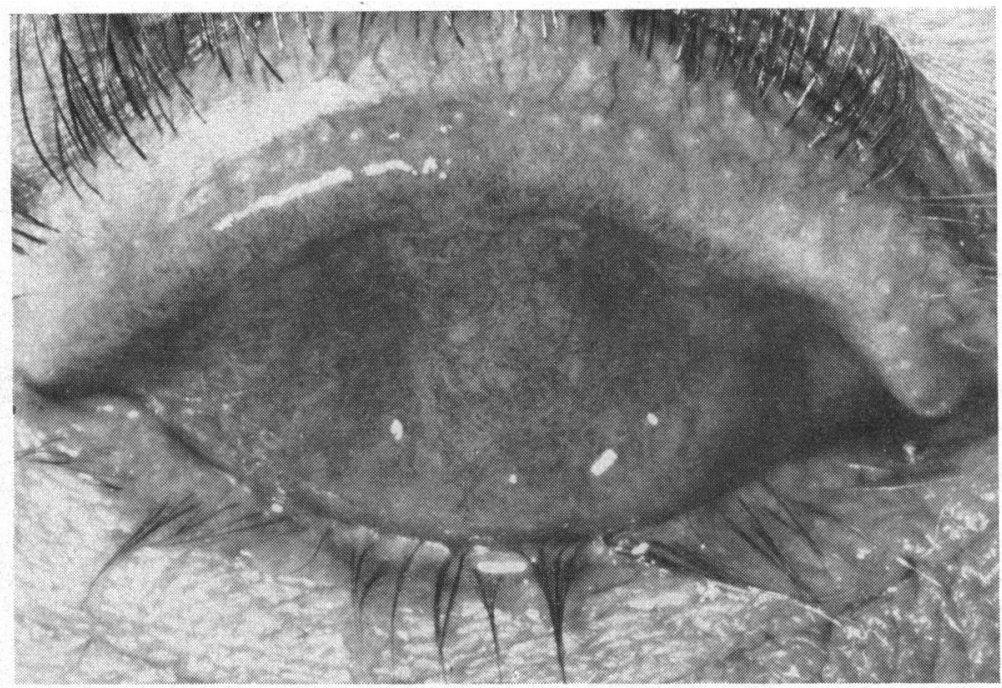

(b)

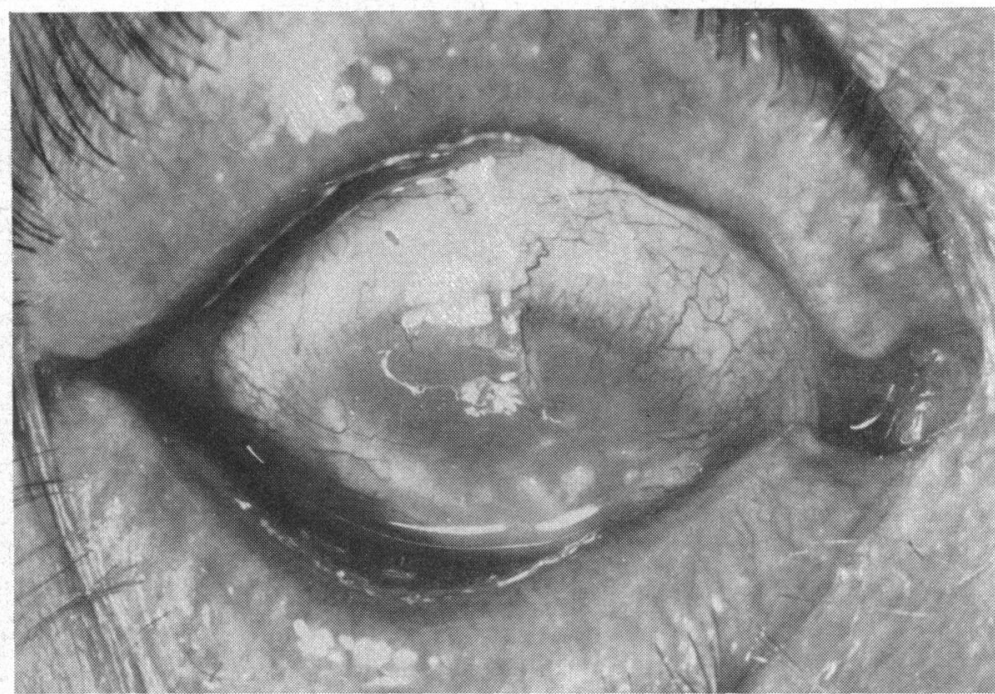

(c)

Fig. 4.-D 50: Right eye, showing numerous follicles amid intense papillary hypertrophy; (b) upper tarsal conjunctiva; (c) punctate and diffuse keratitis. The pannus is less congested and has advanced irregularly.

conjunctiva of the lids and fornices was more solidly infiltrated and granular. On the lower tarsus this was due to papillary hypertrophy. On the plica, caruncle, and fornices, it was due to follicles and on the upper tarsal plate to both papillae and follicles. Some of the follicles were faintly yellowish in colour. The vessels of the pannus were much less engorged but isolated leashes had extended further into the cornea. Further clearing of the cornea as a whole revealed deep vessels coming in from the periphery both above and below. 
The appearance of the left socket remained unaltered on D 1, 3, 6, 15, 20, and 28. The patient was free of symptoms in the left socket until it became "tight." on D 30. Although no alteration in the pre-existing state of chronic inflammation was apparent, the finding of inclusions on D 38 in scrapings from the left socket showed that cross-infection had taken place.

Treatment with Penicillin.-At this stage (D 55) the object of the experiment had been achieved in that the characteristic signs of trachoma in the conjunctiva and cornea had been induced with the formation of typical epithelial inclusion bodies (see below). Although the disease was clearly passing into the chronic phase and the patient was experiencing much less discomfort, the experiment was terminated because of the advent of deep vascularization of the cornea.

In view of the reported efficacy of penicillin in the treatment of trachoma, either by topical administration (Bietti, 1951) or by intramuscular injection (Gilkes, Smith, and Sowa, 1958), it was decided to use this antibiotic. One mega unit was injected intramuscularly daily from D 55 to D 64 inclusive.

From D 56 to D 59 the conjunctiva of the right eye was progressively less hyperaemic, but on D 60,62, 66, and 69 it became gradually more inflamed, until on D 69 the follicles appeared larger and the condition looked more active. From D 56 to D 66 the right cornea continued to clear and no fresh epithelial lesions developed. On D 69, however, there was a return of diffuse epithelial haze with active punctate keratitis.

On D 59 marked oedema and hyperaemia of the conjunctiva of the floor of the left socket and a free mucopurulent discharge were observed, but the pre-existing papillary hypertrophy of the palpebral conjunctiva had not changed. The left pre-auricular node was palpable. On D 60 the conjunctiva was more inflamed and on D 62 the skin at the angles of the left socket was excoriated, follicles were present at the borders of both tarsal plates, and the pre-auricular node was slightly tender and about the size of a pea. The skin of the lid had returned to normal by D 69, but the conjunctiva was more infiltrated.

Treatment with Sulphadiazine.-The improvement in the clinical condition of the right conjunctiva from D 56 to D 59 and in the cornea from D 56 to D 66 may have been due to the penicillin, but this trend had clearly begun between D 50 and D 55 before treatment. The recrudescence of conjunctival and corneal signs of active inflammation in the right eye and the exacerbation of inflammation in the left eye from D 60 to D 69 clearly indicated that penicillin had not cured the condition. As discomfort had returned, the patient was treated with oral sulphadiazine, $2 \mathrm{~g}$. statim and $1 \mathrm{~g}$. four times daily for 10 days from D 70 to D 79 inclusive. 
On D 73 there was a slight improvement in the condition of both eyes. The patient was not seen again by us until D 91 because he developed influenza followed by a severe bronchitis. On D 78 he developed a widespread rash and his general practitioner was uncertain whether this was due to the sulphadiazine or to aspirin in a mixture which he had prescribed for the respiratory infection.

On D 91 the right eye was comfortable with very little discharge. There was much less injection and no oedema, and the follicles were smaller and looked less active. All vessels in the right cornea were obviously receding, the cornea was clearing, and no active epithelial disease was present.

These regressive changes in the right conjunctiva and cornea continued as shown on D 100 (Figs $5 a$, and $5 b$ and $c$, overleaf).

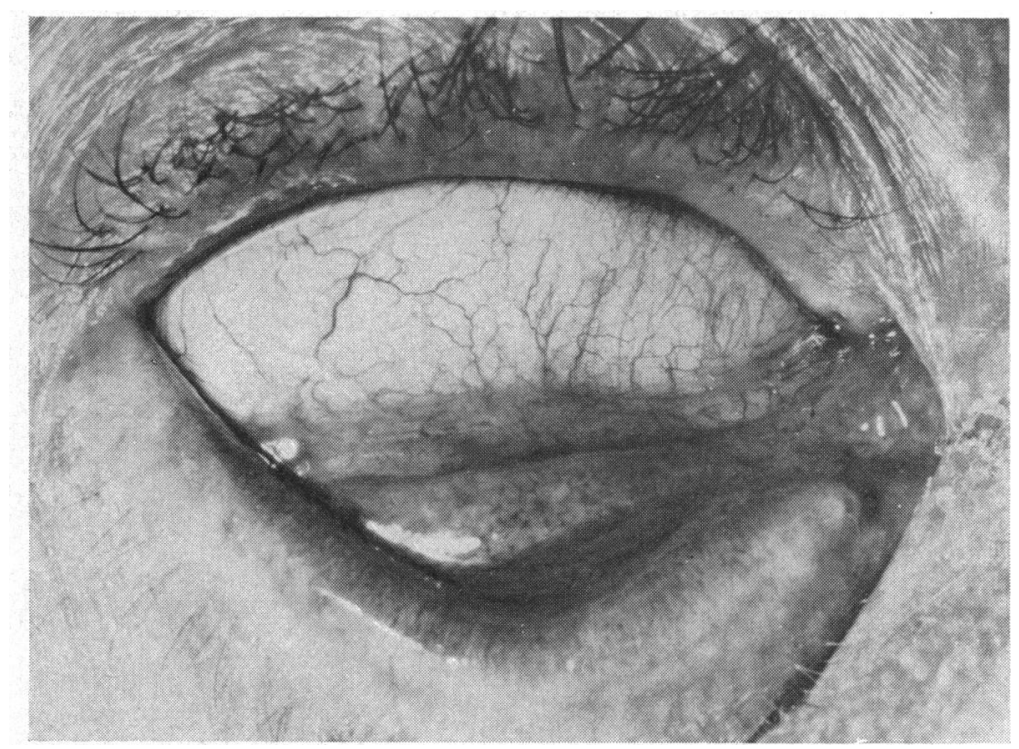

FIG. 5(a).-D 100: Right lower fornix after treatment, showing residual infiltration with papillary hypertrophy and follicles.

By D 108 the right eye was dry and clean and the lacrimal sac was no longer palpable. The follicles were smaller and the conjunctiva paler. Some fine fibrosis was visible in relation to the follicles in the lower fornix and near the upper border of the upper tarsal plate (Fig. 6b, overleaf).

The conjunctival scarring was more definite on D 129, by which time the corneal vessels had greatly regressed and there was only a diffuse and blotchy superficial opacification. On D 145 (Fig. 6, overleaf) there had been further resolution of the follicular hyperplasia and further cicatrization, especially in the conjunctiva over the upper tarsal plate near its upper border. 


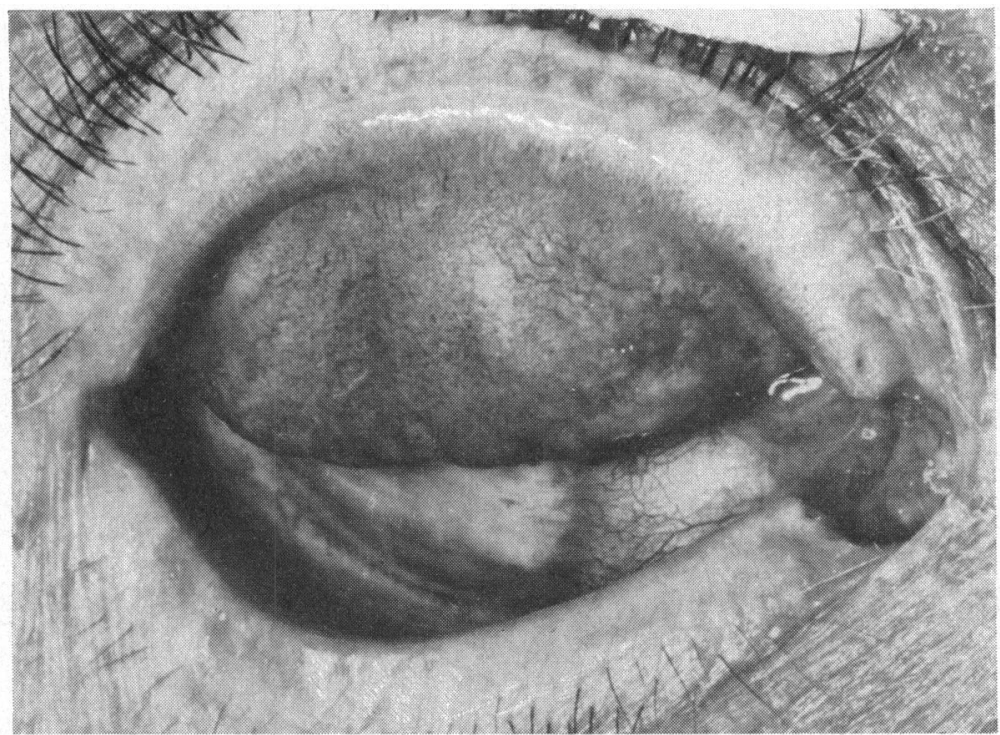

FIG. 5(b).-D 100: Right upper tarsus after treatment, showing early cicatrization at border of upper tarsal plate and residual infiltration with papillary hypertrophy and follicles.

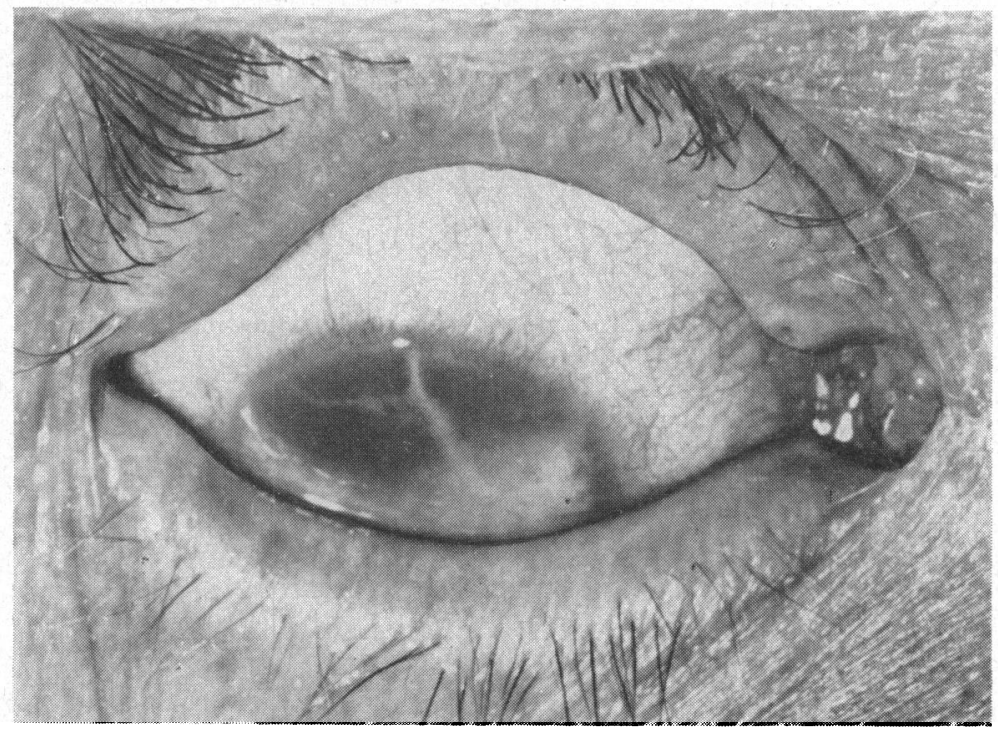

Fig. 5(c).-D 100: Right eye after treatment, showing cornea clearing and pannus receding. 


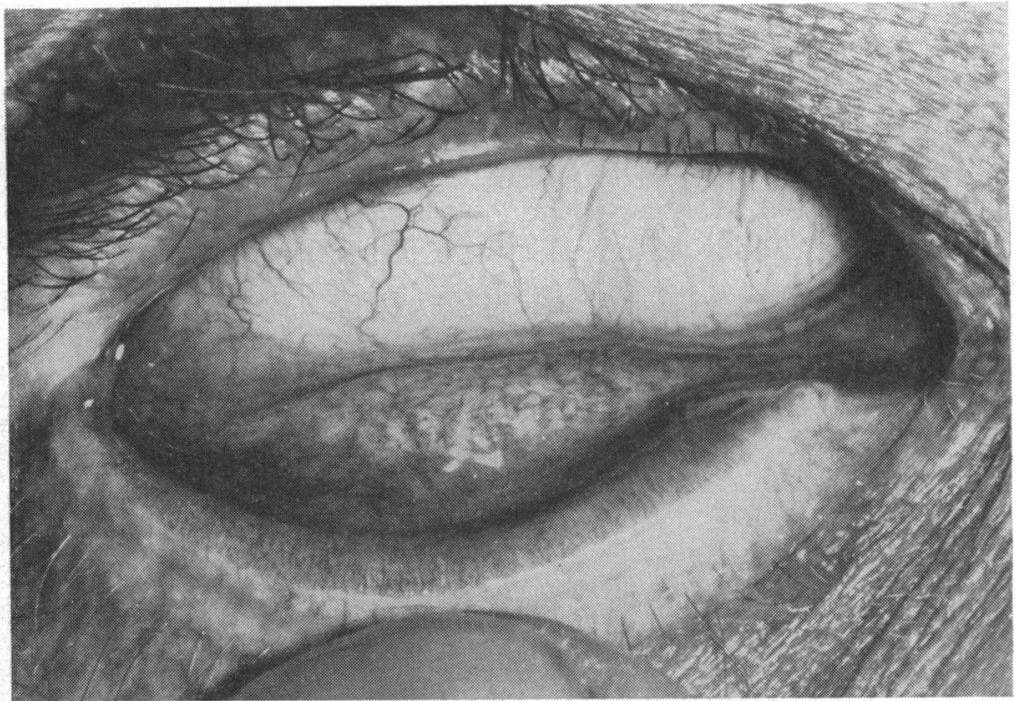

FIG. 6(a).-D 145: Right eye showing further resolution of follicles and papillae in lower lid.

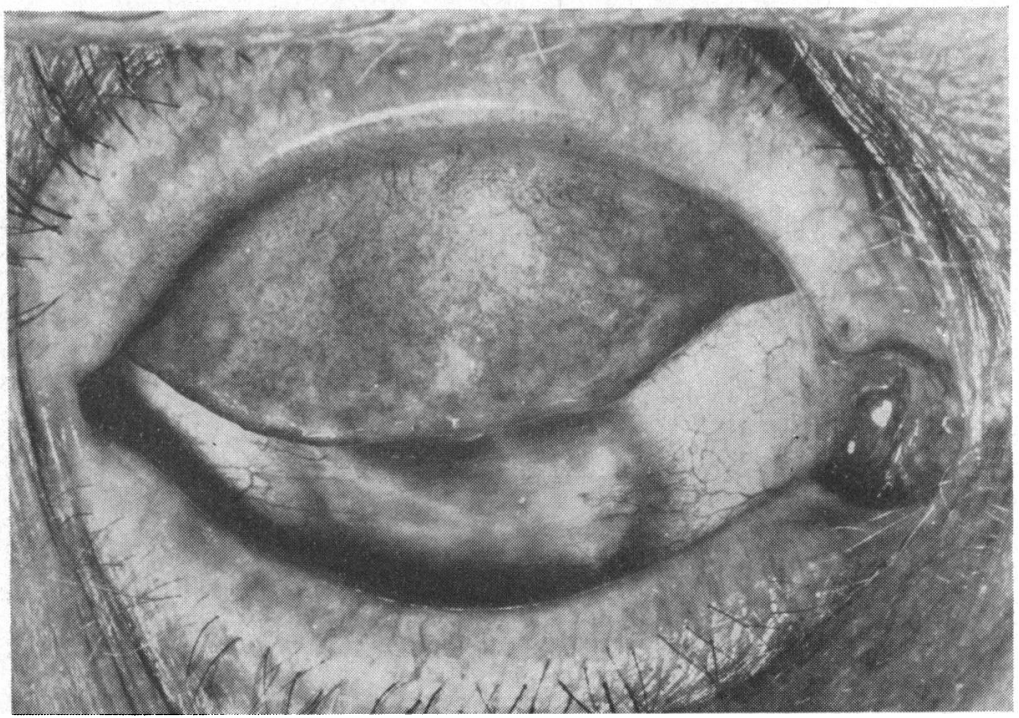

Fig. 6(b).-D 145: Right eye, showing stellate scarring more apparent on upper tarsus. 
Final Examination.-On D 246 (Figs 7a, $b, c$ ) the patient had been entirely free of symptoms for 5 months. The diffuse and follicular infiltration of the conjunctiva had resolved; stellate and linear scarring in the right upper and lower tarsal regions was more obvious. The corneal pannus had disappeared leaving a narrow rim of opacification about the level of Bowman's membrane, and the deep corneal vascularization had regressed. The lacrimal sac and pre-auricular nodes were not palpable.

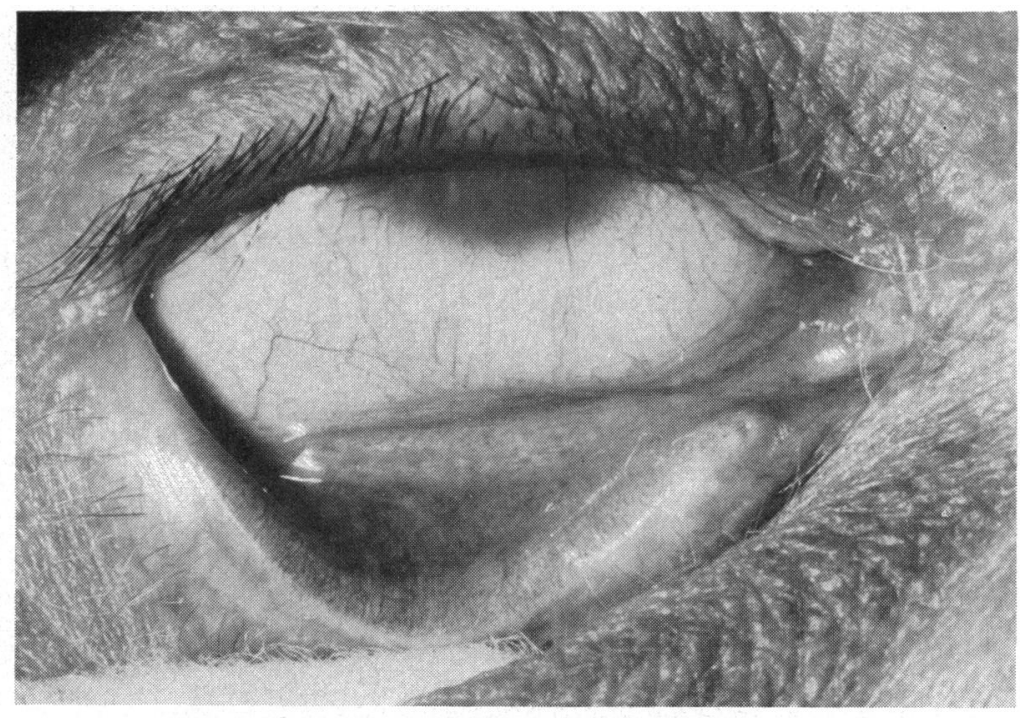

(a)

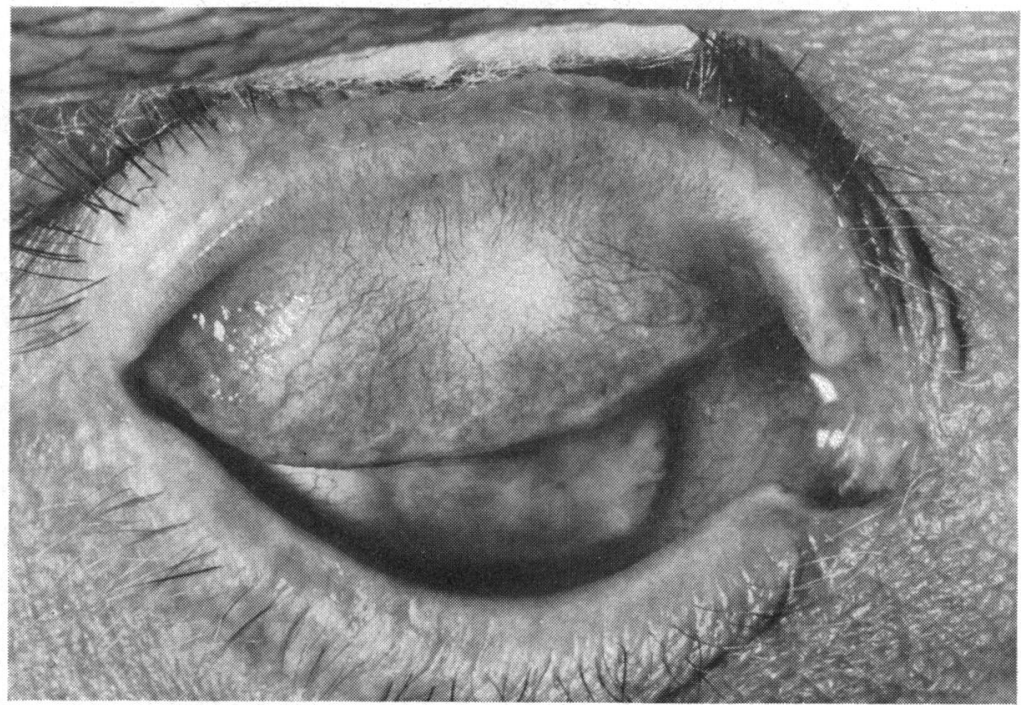

(b)

Fig. 7.-D 246: Right eye, showing normal conjunctiva apart from stellate scars in (a) lower lid and (b) upper lid. 


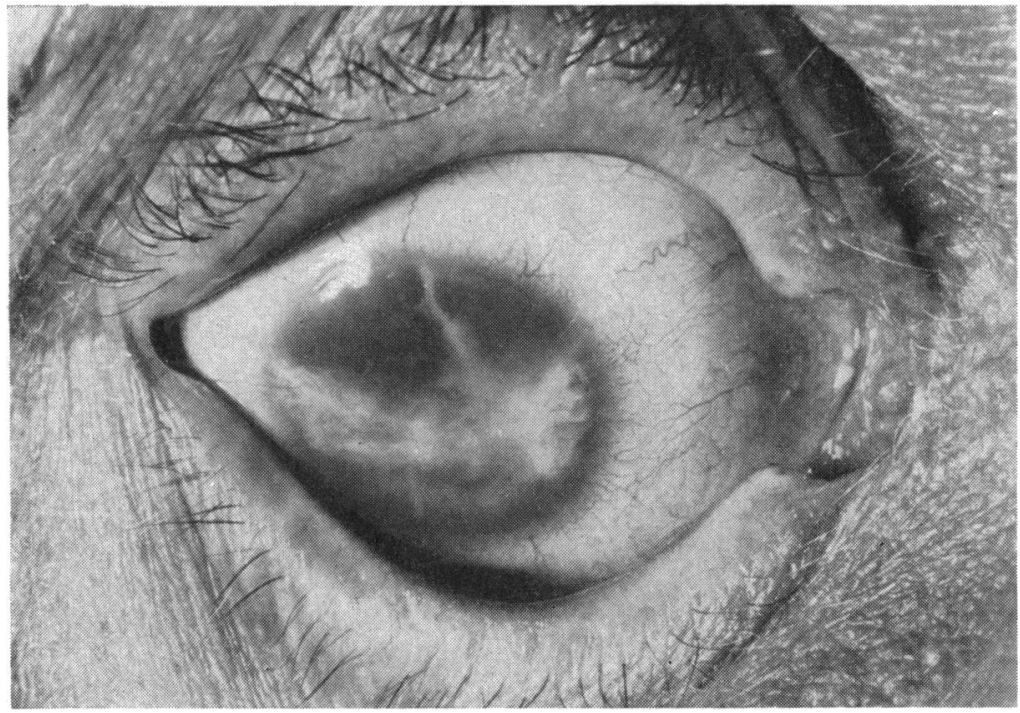

FIG. 7(c).-D 246: Right eye, showing scattered scars in cornea clearing and pannus no longer visible.

On D 91, after sulphadiazine had been administered during the period D 70 to D 79, the left socket had become much less acutely inflamed and oedematous. By D 108 it had returned to its pre-inoculation state apart from slight residual infiltration and follicular reaction near the upper fornix. These had resolved by D 246 leaving no sign of cicatrization.

\section{Laboratory Investigations}

Cytology of Conjunctival Scrapings (Table II, overleaf)

Right (inoculated) Eye.-On the day of inoculation (D 0), only normal epithelial cells were present (Fig. 8).

On D 3, many of the epithelial cells showed marked degenerative changes. The nuclei were swollen, vacuolated, and eosinophilic; the cytoplasm of these cells was often vacuolated or completely lost.

Fig. 8.-D 0: Conjunctival scraping from right eye before inoculation, showing sheets of normal epithelial cells. Stained Giemsa-May Grünwald. $\times 300$.

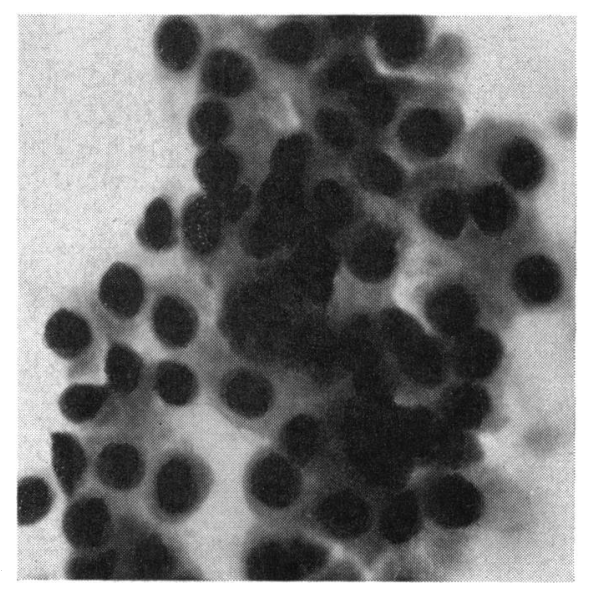


TABLE II

SUMMARY OF VIROLOGICAL AND CYTOLOGICAL FINDINGS

\begin{tabular}{|c|c|c|c|c|c|c|c|c|c|c|c|c|}
\hline \multirow{3}{*}{$\begin{array}{l}\text { Day } \\
\text { after } \\
\text { Inocu- } \\
\text { lation }\end{array}$} & \multicolumn{2}{|c|}{$\begin{array}{l}\text { Virus } \\
\text { Isolation }\end{array}$} & \multicolumn{2}{|c|}{$\begin{array}{l}\text { Epithelial } \\
\text { Inclusions }\end{array}$} & \multicolumn{8}{|c|}{ Cytology of Conjunctival Scrapings } \\
\hline & \multirow{2}{*}{ Right } & \multirow{2}{*}{ Left } & \multirow{2}{*}{ Right } & \multirow{2}{*}{ Left } & \multicolumn{4}{|c|}{ Right } & \multicolumn{4}{|c|}{ Left } \\
\hline & & & & & Po & Ly & $\mathbf{P l}$ & Mo & Po & Ly & Pl & Mo \\
\hline $\begin{array}{lr}\text { D } & 0 \\
\text { D } & 3 \\
\text { D } & 6 \\
\text { D } & 13 \\
\text { D } & 15 \\
\text { D } & 20 \\
\text { D } & 23 \\
\text { D } & 27 \\
\text { D } & 30 \\
\text { D } & 38 \\
\text { D } & 50 \\
\text { D } & 56 \\
\text { D } & 57 \\
\text { D } & 58 \\
\text { D } & 59 \\
\text { D } & 60 \\
\text { D } & 62 \\
\text { D } & 63 \\
\text { D } & 64 \\
\text { D } & 66 \\
\text { D } & 70 \\
\text { D } & 71 \\
\text { D } & 72 \\
\text { D } & 73 \\
\text { D } & 74 \\
\text { D } & 89 \\
\text { D } & 98 \\
\text { D } & 106 \\
\text { D } & 112 \\
\text { D } & 140 \\
\text { D } & 245\end{array}$ & $\begin{array}{l}\text { C } \\
\text { Pos } \\
- \\
- \\
\text { Pos } \\
- \\
\text { Pos } \\
- \\
\text { C } \\
\text { C } \\
\text { 0 } \\
\text { Pos } \\
\text { Pos } \\
\text { Pos } \\
0 \\
\text { C } \\
- \\
0 \\
\text { C } \\
0 \\
\text { Pos } \\
0 \\
0 \\
0 \\
0 \\
0 \\
\text { C } \\
\text { C } \\
0 \\
0 \\
-\end{array}$ & $\begin{array}{l}\text { C } \\
0 \\
- \\
- \\
0 \\
- \\
0 \\
- \\
0 \\
\text { C } \\
0 \\
- \\
0 \\
0 \\
0 \\
0 \\
- \\
0 \\
0 \\
0 \\
\text { Pos } \\
0 \\
0 \\
0 \\
0 \\
0 \\
\text { C } \\
0 \\
0 \\
-\end{array}$ & $\begin{array}{rr}0 & \\
+ & + \\
& + \\
& + \\
& + \\
+ & + \\
& - \\
& + \\
+ & + \\
+ & + \\
& + \\
& + \\
+ & + \\
0 & + \\
0 & \\
& + \\
0 & \\
0 & \\
& + \\
0 & \\
0 & \\
0 & \\
& + \\
0 & \\
0 & \\
& + \\
0 & \\
0 & \\
0 & \\
0 & \\
0 & \\
0 & \end{array}$ & $\begin{array}{c}0 \\
0 \\
0 \\
0 \\
0 \\
0 \\
- \\
0 \\
0 \\
+++ \\
0 \\
- \\
0 \\
+++ \\
\\
0 \\
0 \\
0 \\
0 \\
0 \\
0 \\
+ \\
0 \\
+ \\
0 \\
0 \\
0 \\
0 \\
0 \\
0 \\
+\end{array}$ & $\begin{array}{r}0 \\
++ \\
+ \\
+ \\
- \\
+ \\
- \\
+ \\
+ \\
+ \\
+ \\
++ \\
++ \\
++ \\
++ \\
++ \\
++ \\
++ \\
++ \\
+ \\
+ \\
+ \\
+ \\
+ \\
+ \\
+ \\
+ \\
+ \\
+ \\
+ \\
+\end{array}$ & 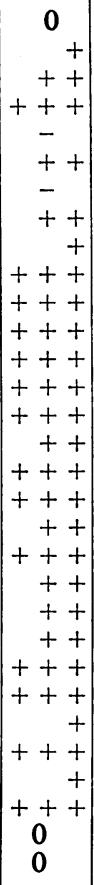 & $\begin{array}{c}0 \\
0 \\
+ \\
+ \\
- \\
+ \\
- \\
+ \\
+ \\
+ \\
+ \\
++ \\
+ \\
+ \\
0 \\
0 \\
0 \\
+ \\
0 \\
+ \\
0 \\
0 \\
+ \\
+ \\
0 \\
0 \\
+ \\
0 \\
0 \\
0 \\
0\end{array}$ & 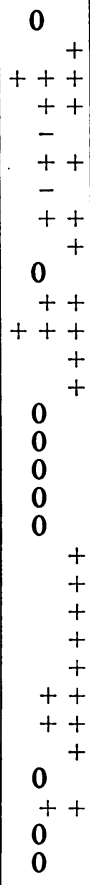 & $\begin{array}{r}+++ \\
+++ \\
+++ \\
+++ \\
- \\
+++ \\
- \\
+++ \\
+++ \\
++ \\
+++ \\
- \\
+++ \\
+++ \\
+++ \\
++ \\
+++ \\
+++ \\
+++ \\
++ \\
+++ \\
++ \\
+++ \\
++ \\
+++ \\
+++ \\
+++ \\
+++ \\
+++ \\
+++\end{array}$ & $\begin{array}{c}0 \\
0 \\
0 \\
0 \\
0 \\
- \\
+ \\
+ \\
++ \\
++ \\
- \\
++ \\
++ \\
++ \\
++ \\
+ \\
++ \\
++ \\
++ \\
++ \\
++ \\
++ \\
++ \\
++ \\
++ \\
++ \\
+ \\
++ \\
++ \\
+\end{array}$ & $\begin{array}{c}0 \\
0 \\
0 \\
0 \\
- \\
0 \\
- \\
0 \\
0 \\
+ \\
0 \\
- \\
+ \\
+ \\
+ \\
0 \\
0 \\
+ \\
+ \\
+ \\
0 \\
0 \\
+ \\
+ \\
0 \\
0 \\
+ \\
0 \\
0 \\
0 \\
0\end{array}$ & 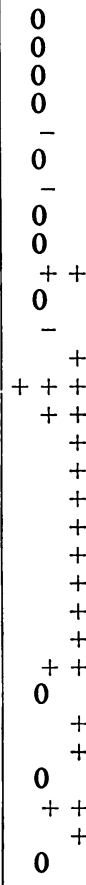 \\
\hline $\begin{array}{l}\mathbf{L y}=\mathbf{L y} \\
\mathbf{P I}=\mathbf{P l} \\
\mathrm{Mo}=\mathrm{La}\end{array}$ & $y$ & 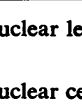 & & $\begin{array}{l}\text { C }= \\
\text { Pos. } \\
0^{-}=\end{array}$ & $\begin{array}{l}\text { ot examin } \\
\text { egative or }\end{array}$ & $\begin{array}{l}\text { inated } \\
\text { bsent }\end{array}$ & & & $\begin{array}{l}++= \\
++=\end{array}$ & $\begin{array}{l}\text { rate } \\
\text { nume }\end{array}$ & s loer & \\
\hline
\end{tabular}

Numerous polymorphonuclear leucocytes were seen with a few lymphocytes and large mononuclear cells (Figs $9 a, b$, opposite).

By D 6, plasma cells had appeared; the polymorphs had diminished in number, but there was an increase in lymphocytes. This cytological picture persisted until 4 days after the start of penicillin treatment on D 55, when plasma cells and large mononuclear leucocytes were less numerous. On D 38 (when cross-infection of the left eye was confirmed), there were exceptionally numerous inclusions, and the degenerative changes in the epithelium were more severe than on any other occasion (Fig. 10, opposite).

Degenerative changes were evident in epithelial cells throughout the treatment with penicillin and sulphadiazine and were still present on D 245; however, they were noticeably less on and after D 106, a month after completing treatment with sulphadiazine. 


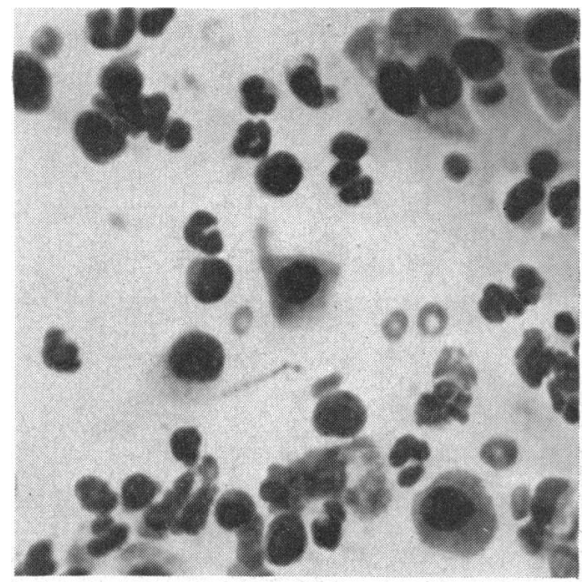

(a)

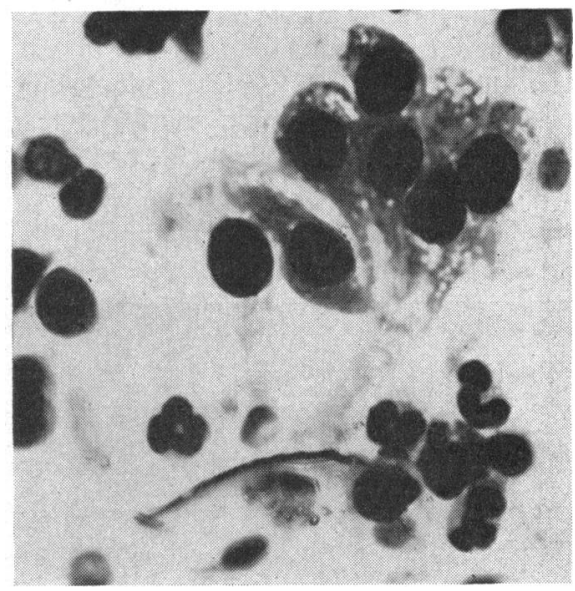

(b)

FIG. $9(a$ and $b$ ).-D 3: Conjunctival scraping from right eye, showing polymorphs, lymphocytes, and scattered epithelial cells, some with vacuolated cytoplasm. Stained Giemsa-May Grünwald. (a) $\times 300 ;(b) \times 360$.

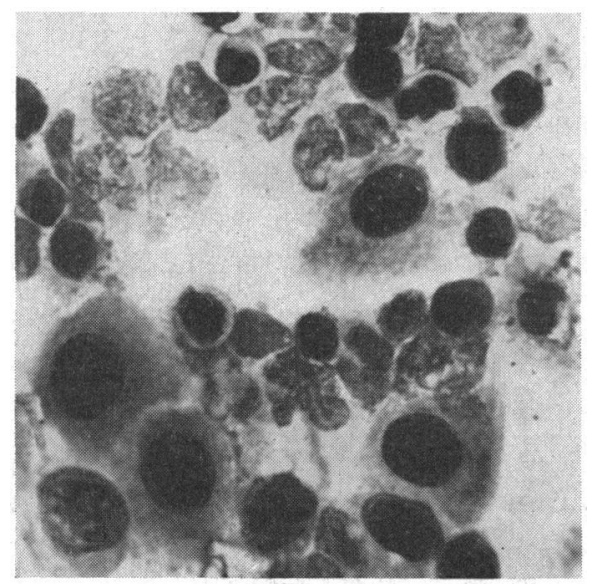

Fig. 10.-D 38: Conjunctival scraping from right eye, showing marked degenerative changes in epithelial cells, and much cytoplasmic debris. Stained Giemsa-May Grünwald. $\times 360$.

Left (control) Socket.-At the outset the epithelial cells appeared normal, but numerous polymorphs were present. On D 27, degenerative changes were seen similar to those in the right eye, and a few lymphocytes appeared. On D 38, the cytology of conjunctival scrapings from the left conjunctiva were characteristic of trachoma. Some of the epithelial cells were degenerate, and moderate numbers of polymorphs, lymphocytes, large mononuclear cells, and plasma cells were seen; inclusions were plentiful.

This cytological picture persisted until completion of treatment with sulphadiazine. The epithelial cells then became progressively more normal in appearance; plasma cells were rarely found, although lymphocytes were present up to and including D 245.

\section{Inclusion Bodies (Table II)}

Right Eye.-On D 3, a moderate number of inclusions was found in scrapings from the right eye, mostly initial body forms and small Halberstaedter-Prowazek bodies 
(HPK). Numerous free elementary bodies were also present (Fig. 11). On D 6, several large inclusions were seen, which stained well with iodine, and until the start of penicillin treatment on D 56, typical cytoplasmic inclusions were found at every examination (Fig. 12); they were particularly numerous on D 38, when the cytological findings (see above, Fig. 10) also indicated an exacerbation of the infection.

Left (control) Socket.-On D 38, scrapings from the left conjunctiva contained many inclusions, indicating that cross-infection had taken place.

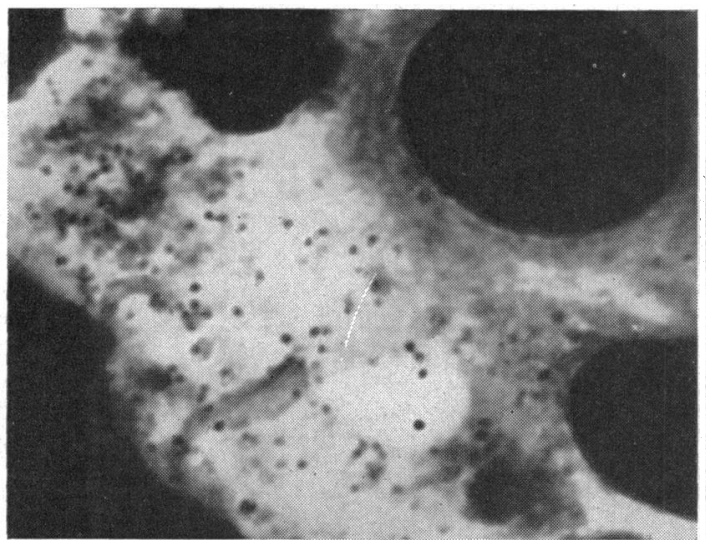

FIG. 11.-D 3: Conjunctival scraping from right eye, showing numerous free elementary bodies. Stained Giemsa-May Grünwald. $\quad \times 1200$.

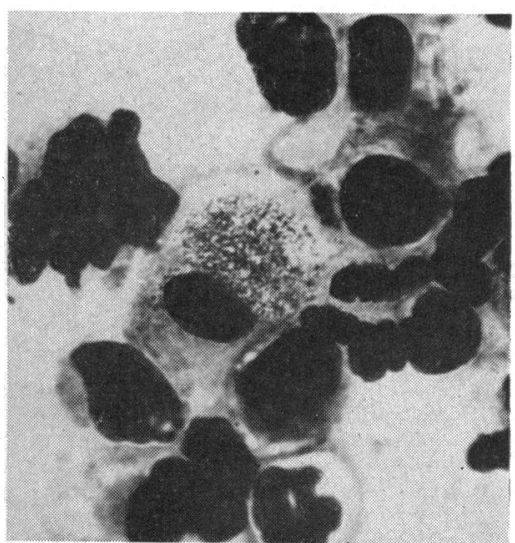

FIG. 12.-D 6: Conjunctival scraping from right eye, showing a large Halberstaedter-Prowazek inclusion body. Stained Giemsa-May Grünwald. $\times 615$.

Influence of Therapy on Morphology of Inclusions.-From D 55 to D 64 inclusive, a daily intramuscular dose of 1 mega unit penicillin was given. On D 57 there were still many inclusions, a few of which had features characteristic of the early stages of antibiotic treatment. In some, the elementary bodies were grossly irregular in size and shape, measuring from $0 \cdot 25$ to $2 \mu$ in diameter (Fig. $13 a$ and $b$ ).

(a)
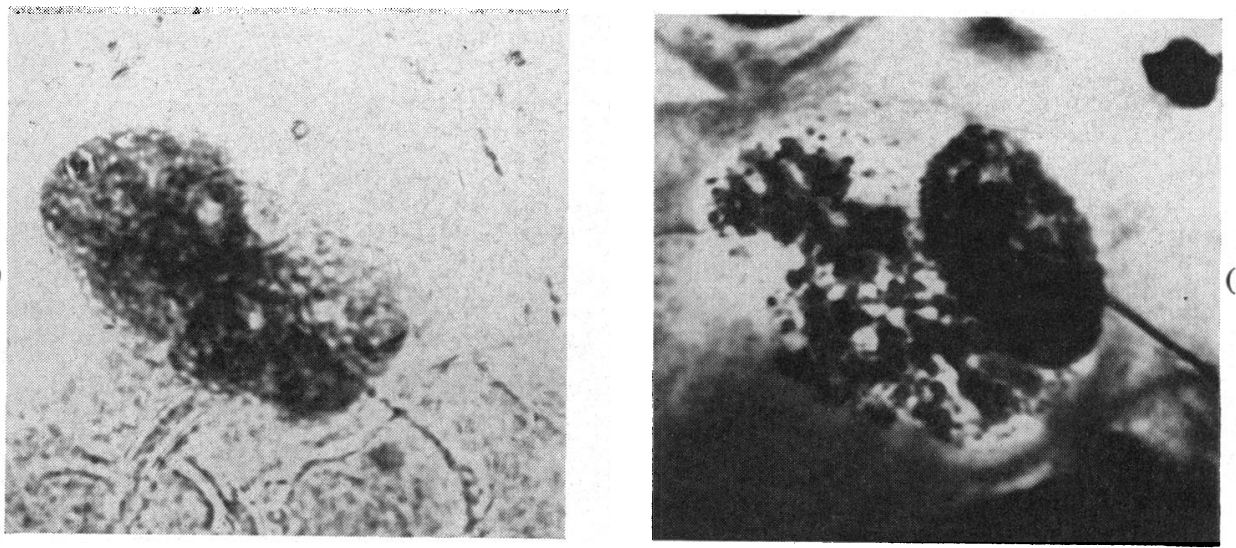

FIG. 13.-D 58: Conjunctival scraping from right eye. (a) Atypical Halberstaedter-Prowazek inclusion body with large matrix. Stained iodine. $\times 1200$. (b) Same field after decolourization and re-staining with Giemsa-May Grünwald, showing swollen elementary bodies. $\times 1200$. 
In others, the inclusion consisted of a vacuole containing irregular masses of eosinophilic material. Inclusions were occasionally found throughout the period of treatment with penicillin; on and after the fifth day most of them were degenerate, but as late as the second day after completing the treatment typical HPK were present.

Since both the laboratory and clinical findings showed that penicillin was not fully effective, a course of sulphadiazine was given by mouth from D 70 to D 79 inclusive. On D 71, both typical and degenerate inclusions were present in conjunctival scrapings. On D 72 and D 74 scanty degenerate inclusions were present. All were vacuolated and contained ill-defined eosinophilic material. Thereafter no further inclusions were observed.

Virus Isolation (Table II).-At intervals attempts were made to isolate virus from both eyes by chick embryo inoculation. The results are summarized in Table II. It is noteworthy that virus was isolated on the first and second day of penicillin treatment, and again 6 days after completing the course. This accords with the finding of typical conjunctival inclusions during the same period.

Attempts to isolate virus after beginning sulphadiazine therapy were all negative.

The aggregates of elementary bodies characteristic of the infecting virus strain G17 were again found in yolk-sac smears on each occasion that virus was isolated during the experimental infection.

Serology.-Complement-fixation tests were made on sera taken on D 0, D 27, and D 246. The sera were separated shortly after collection, and preserved with sodium azide at $+4^{\circ} \mathrm{C}$. until testing. The titrations were all made at the same time. There was a slight but significant rise in antibody titre to both Gambian and Chinese strains of trachoma virus, and to psittacosis antigen (Table III).

TABLE III

COMPLEMENT-FIXATION TESTS ON SERA OF HUMAN SUBJECT

\begin{tabular}{|c|c|c|c|c|c|}
\hline & \multirow{3}{*}{ Antigen } & & \multicolumn{3}{|c|}{ Serum Titre } \\
\hline & & & \multirow{2}{*}{$\begin{array}{c}\text { Before } \\
\text { Inoculation }\end{array}$} & \multicolumn{2}{|c|}{ After Inoculation } \\
\hline & & & & D27 & D372 \\
\hline \multirow[t]{3}{*}{ Trachoma Virus } & Gambian Strain G1 & .. & $<\frac{1}{4}$ & $\frac{1}{8}$ & $\frac{1}{4}$ \\
\hline & Gambian Strain G17 & .. & $<\frac{1}{4}$ & $\frac{1}{8}$ & $\frac{1}{4}$ \\
\hline & T'ang's Strain TE55 & .. & $<\frac{1}{4}$ & $\frac{1}{8}$ & $\frac{1}{4}$ \\
\hline \multicolumn{2}{|l|}{ Psittacosis Virųs } & .. & $<\frac{1}{4}$ & $\frac{1}{8}$ & $\frac{1}{4}$ \\
\hline \multicolumn{2}{|c|}{ Normal Yolk-Sac Control } & .. & $<\frac{1}{4}$ & $<\frac{1}{4}$ & $<\frac{1}{1}$ \\
\hline
\end{tabular}

Skin Tests.-On D 1, several antigens in amounts of $0.1 \mathrm{ml}$. were injected intracutaneously into the flexor surfaces of the forearms. The results were read at intervals 
during the 13 days following the conjunctival inoculation (Table IV). The Frei antigen induced a papular lesion which persisted for 6 days, and an erythematous area was still visible on D 13. Since the control for this antigen also induced a small papular lesion, its significance is doubtful. The antigens prepared from the infecting trachoma strain G17 induced papular lesions $48 \mathrm{hrs}$ after injection; these had disappeared by D 6 . On D 9, however, papules were present at the site of all the trachoma virus injections; no lesions were induced by the control for these antigens throughout the period of observation. The significance of the lesions appearing at $48 \mathrm{hrs}$ is not clear; the later lesions may have been due to the development of skin sensitivity pari passu with the infective process in the conjunctiva.

TABLE IV

SIZE AND NATURE OF SKIN REACTIONS TO VIRUS ANTIGENS INJECTED ON SAME DAY OF CONJUNCTIVAL INOCULATION WITH TRACHOMA VIRUS

\begin{tabular}{l|c|c|c|c|c|c|c|c}
\hline \multirow{2}{*}{ Antigen } & \multicolumn{6}{c|}{ No. of Days after Conjunctival Inoculation } \\
\cline { 2 - 8 } & \multicolumn{2}{|c|}{3} & \multicolumn{2}{|c|}{6} & \multicolumn{2}{c}{9} & \multicolumn{2}{c}{13} \\
\cline { 2 - 8 } & $\begin{array}{c}\text { Size } \\
(\mathrm{mm} .)\end{array}$ & Lesion & $\begin{array}{c}\text { Size } \\
(\mathrm{mm} .)\end{array}$ & Lesion & $\begin{array}{c}\text { Size } \\
(\mathrm{mm} .)\end{array}$ & Lesion & $\begin{array}{c}\text { Size } \\
(\mathrm{mm} .)\end{array}$ & Lesion \\
\hline Frei & $7 \times 9$ & EP & $7 \times 10$ & EP & $6 \times 9$ & E & $6 \times 10$ & E \\
\hline Frei Control & $4 \times 5$ & EP & Nil & - & $4 \times 4$ & P & Nil & - \\
\hline Trachoma G1 .. & Nil & - & Nil & - & $5 \times 5$ & EP & Nil & - \\
\hline Trachoma G17 .. & $4 \times 4$ & P & Nil & - & $5 \times 5$ & EP & Nil & - \\
\hline Trachoma Control & Nil & - & Nil & - & Nil & - & Nil & - \\
\hline
\end{tabular}

Bacteriological Examinations.-On most of the occasions when conjunctival scrapings were made, bacteriological swabs were also taken from both eyes and seeded onto blood agar plates which were incubated aerobically at $37^{\circ} \mathrm{C}$. No growth was obtained from either eye from D 38 to D 57, but on almost every other occasion the swabs yielded scanty or moderate growths of Corynebacterium xerosis, and occasionally a few colonies of micrococci or diphtheroids.

On D 112, the right eye yielded three colonies of coagulase-positive staphylococci.

Haematology.-At the outset of the experiment (D 0 ), the following values were obtained:

Red blood count 5,000,000/cu. mm.; haemoglobin $13 \cdot 3 \mathrm{~g} . / 100 \mathrm{ml}$.; mean cell volume $86 \mathrm{cu} . \mu$; mean cell haemoglobin $26 \mu \mu \mathrm{g}$. Erythrocytes showed slight anisocytosis and hypochromia. White blood count 8,800/cu. mm.: neutrophils 61 per cent.; eosinophils 1 per cent.; lymphocytes 35 per cent.; monocytes 3 per cent. Erythrocyte sedimentation rate $21 \mathrm{~mm}$./ hr (normal 1 to $10 \mathrm{~mm}$.).

On D 27, the white cell count was 6,800/cu. mm.: neutrophils 57 per cent.; eosinophils 4 per cent.; lymphocytes 33 per cent.; monocytes 6 per cent. Erythrocyte sedimentation rate 20 $\mathrm{mm} . / \mathrm{hr}$.

On D 89, the white cell count was $7,600 / \mathrm{cu}$. mm., and the differential count almost identical with that made on $\mathbf{D} 0$. 


\section{Discussion}

The inoculation of the right eye with virus strain G17 (at the 18th egg passage) was followed by the acute onset of a severe mucopurulent papillary and follicular conjunctivitis with mild pre-auricular adenitis. This proceeded to a chronic disease with interstitial cicatrization of the conjunctiva. There was an associated diffuse roughening and opacification of the corneal epithelium which led to a punctate epithelial and subepithelial keratitis, trachoma pustules, and pannus. These signs establish an unequivocal clinical diagnosis of trachoma.

The inclusions with iodine-staining matrices and the cytology of conjunctival scrapings were also typical of trachoma. The repeated re-isolation of virus having the same unusual morphology in eggs as the strain used for inoculation, the consistent absence of bacteria other than commensals, and the rise in titre of complement-fixing antibodies in the patient's serum clearly indicate that the clinical disease was associated with an infection by virus G17.

Inoculation of a control yolk-sac suspension into the left socket did not alter the pre-existing state of chronic inflammation, but about one month after inoculation the socket became cross-infected from the right eye.

Although intramuscular penicillin produced a temporary amelioration of the clinical disease and formation of atypical inclusions, it is clear that it did not have sufficient effect on the virus to eradicate the infection, either in the right eye in the early chronic stage, or in the left socket which had recently become infected and was in the acute stage.

The administration of oral sulphadiazine resulted in the disappearance of the virus and the resolution of the clinical and cytological features of the disease.

This experiment clearly shows that virus strain G17 is aetiologically related to trachoma.

\section{SUMmaRY}

This paper describes the second successful inoculation of a human volunteer with virus isolated from a trachomatous patient and subjected to serial passage in the laboratory. The typical clinical picture of trachoma in both conjunctiva and cornea resulted; the cytology of the conjunctival scrapings and the epithelial inclusion bodies were typical of trachoma; the virus was repeatedly re-isolated from the conjunctiva, which remained free of bacteria other than commensals. The disease in the inoculated eye and the late cross-infection which occurred in the other conjunctiva were terminated by the administration of oral sulphadiazine. It is thus established that the virus strain tested is aetiologically related to trachoma. 
We are indebted to Professor C. F. Barwell (The London Hospital) for supplying the Frei antigen and control, to our colleague Mr. Peter Reeve for performing the complement-fixation titration, and to the Department of Pathology, Institute of Ophthalmology, for the bacteriological and haematological investigations.

Our greatest debt, of course, is to the man whb volunteered to be the subject for inoculation. The observations took a great deal of time and for a period he was in discomfort which he bore with the greatest equanimity.

\section{REFERENCES}

BIETTI, G. (1951). WHO/Trachoma/17.

COLlier, L. H. (1959). Brit. med. Bull., 15, 231.

, Duke-Elder, S., and JONeS, B. R. (1958). Brit. J. Ophthal., 42, 705. and SowA, J. (1958). Lancet, 1, 993.

DulbecCo, R., and VoGt, M. (1954). J. exp. Med., 99, 167.

GILKES, M. J., SMITH, C.H., and SowA, J. (1958). Brit. J. Ophthal., 42, 478.

ReEd, L. J., and MuenCH, H. (1938). Amer. J. Hyg., 27, 493.

SOWA, J., and CollieR, L. H. (1960). J. Hyg., in press. 